\title{
Aurelia Kothiewicz
}

Uniwersytet Pedagogiczny im. KEN w Krakowie

iD

\section{SPRAWOZDANIE}

\section{Z XIII MIĘDZYNARODOWEJ KONFERENCJI NAUKOWEJ LITERATURA JEDNEGO DOMU (24-25 PAŹDZIERNIKA 2019 ROKU, PETERSBURG)}

\section{LITERATURA JEDNEGO DOMU}

W dniach 25-26 października 2019 roku w Petersburgu odbyła się doroczna, trzynasta już Międzynarodowa Konferencja Naukowa „Literatura jednego domu”, zorganizowana przez Państwowe Muzeum Literatury XX wieku we współpracy z Rosyjską Akademią Nauk. Konferencja ma już swoją tradycję i od początku poświęcana jest pisarzom, których los związał z domem nr 9 nad kanałem Gribojedowa, na stałe wpisanym w pejzaż Petersburga.

W domu nad brzegiem Mojki, przeznaczonym w początkach swojego istnienia na mieszkania dla muzyków orkiestry dworskiej cara Aleksandra III, na początku lat 30. XX wieku, w dwóch, dobudowanych do niego piętrach zamieszkali wybitni twórcy dwudziestowiecznej kultury rosyjskiej: Michaił Zoszczenko, Michaił Słonimski, Wieniamin Kawierin, Jewgienij Szwarc, Nikołaj Olejnikow, Nikołaj Zabołocki, Borys Tomaszewski, Borys Eichenbaum i wielu innych. 
Bohaterem szczególnym kolejnych edycji konferencji jest Michaił Zoszczenko, najbardziej znany mieszkaniec domu. W roku 2019 obchodzono jubileuszową 125. rocznicę urodzin pisarza. Oprócz tematyki, dotyczącej życia i spuścizny artystycznej twórców związanych z domem (Вокруг Зощенко), tematem wystąpień prelegentów - literaturoznawców, muzeologów, historyków sztuki z Rosji, Polski, Litwy i Włoch - była także historia literatury i kultury Leningradu/Petersburga XX i XXI wieku (Из истории ленинградской литературы и Писательского дома). Obrady toczyły się w siedzibie Instytutu Literatury Rosyjskiej Akademii Nauk (Puszkinskij dom) oraz w Muzeum Michaiła Zoszczenki, byłym mieszkaniu autora Arystokratki.

Wiaczesław Muromski, emerytowany profesor Instytutu Literatury Rosyjskiej w Petersburgu, wybitny znawca twórczości Michaiła Zoszczenki, autor wielu artykułów i książek na ten temat, przedstawił referat dotyczący dramaturgii Zoszczenki ( $К$ выходу из печати книги „Театр Зощенко”. Попутные размышления). Temat wystąpienia pośrednio związany był z wydaną pod redakcją Muromskiego w 2018 roku książką Teamp Зощенккo, w której zamieszczono dziesięć jego sztuk teatralnych. Wystąpienie moskiewskiego badacza, Dmitrija Nikołajewa, poświęcone było współpracy Michaiła Zoszczenki z czasopismem satyrycznym „Krokodyl” („Жить стало лучше, товарищи. Жить стало веселее!”: М. Зощенкко в журнале „Крокодил” в 1936 г.). Biograficzny aspekt badań nad życiem i twórczością autora Przywróconej młodości omówiony został przez badaczkę łotewską Jelenę Romaszową (Мистификaции и другие загадки Зощенко и невольные ошибки его биографов). Ważnym przyczynkiem dla poznania biografii pisarza i istniejących w niej jeszcze „białych plam”, dotyczących najbardziej tragicznego okresu w jego życiu po 1946 roku i rezolucji Andrieja Żdanowa, są nieznane listy pisarza. Temu tematowi zostało poświęcone wystąpienie Tatiany Carkowej (Неизвестные письма Зощенко последних лет). Kolejne referaty związane z życiem i twórczością Zoszczenki dotyczyły bohaterów jego prozy (Lidia Posadska, Герой М. Зощенко как субъект массовой культурь), pisarza w roli czytelnika książek (Aleksiej Siomkin, „Ужасно быть 
в плену у книг". Зощенко как читатель. Из опыта работы над выставкой о библиотеке Зощенко), Zoszczenki - krytyka i interpretatora poezji (Jurij Orlicki, Зощенко как критик и интерnретатор поэзии), wreszcie - Zoszczenki jako scenarzysty (Jelena Socziwko, Зощенко как киносиенарист (с демонстрацией $\kappa / \oint$ „Преступление и наказание”)).

Dwa wystąpienia poświęcone zostały relacjom pisarza $\mathrm{z}$ innymi twórcami epoki oraz ich recepcji utworów Zoszczenki (Aleksiej Jeliaszewicz, „Чудо обыденной речи”: рецепция поэтики Михаила Зощенко в дневниках Геннадия Алексеева; Jelena Kuranda, М.М. Зощенко и В.Г. Адмони).

Pozostałe referaty konferencyjne tematycznie związane były zarówno z Domem Pisarzy, jak i z historią literatury Leningradu/Petersburga, rozpatrywaną w szerokim kontekście kulturowym i historycznym.

Jednym z najbardziej traumatyzujących wydarzeń w historii miasta, które znalazło swój wyraz literacki w wielu utworach artystycznych, dziennikach, wspomnieniach, było oblężenie. Tej tematyce poświęcone zostały dwa referaty konferencyjne. Natalia Prozorowa, odwołując się do materiałów źródłowych, opowiedziała o wpływie sytuacji oblężenia na twórców (Natalia Prozorowa, Пuсатель и блокада: реконструкиия новогоднего вечера 31 декабря 19412. В Доме писателя им. В.В. Маяковского (анализ источников)). Z kolei polskie badaczki, Aurelia Kotkiewicz i Beata Pawletko, przedstawiły recepcję twórczości Olgi Bergholc w Polsce (Нuкmo не забыт и ничто не забыто? О творчестве Ольги Берггольи, в Польше).

Borys Ryży i Aleksander Kuszner — jedni z najbardziej utalentowanych poetów II połowy XX wieku, których twórczość wpisuje się w petersburski tekst literatury rosyjskiej, byli bohaterami opowieści Anatolija Sobiennikowa (Петербургский текст Бориса Рьжего) i Anatolija Kułagina (Сирень в поэтическом мире А. Кушнера).

Trzy wystąpienia konferencyjne poświęcone zostały satyrycznemu nurtowi w literaturze rosyjskiej XX wieku. Włoska badaczka, Marta Valeri, w swoim referacie omówiła wizerunek mieszczanina, jednego z ważniejszych bohaterów radzieckiej i włoskiej satyry 
pierwszej połowy XX wieku (По закону пошлости. Образ мещанина в российской и итальянской сатире первой половины $X X$ в.). Satyra rosyjska spod znaku Zoszczenki znalazła wielu kontynuatorów, by wymienić choćby takich pisarzy jak Siergiej Dowłatow czy Wiktor Goliawkin, niesłusznie zapomniany pisarz i malarz (Ksenia Prichotko, Голявкин и Довлатов: соседи по алфавиту), a także Anatolij Gładilin, Wasilij Aksionow i Wieniedikt Jerofiejew (Galina Dobrozrakowa, Постдовлатовский феномен: анекдот в автобиограбической прозе современных писателей).

Do kanonu petersburskiego tekstu literatury rosyjskiej należy twórczość pisarzy i poetów, zamieszkałych w słynnym domu nad kanałem Gribojedowa i skupionych wokół ugrupowania Oberiu: Konstantina Waginowa, Walentina Stienicza, Jewgienija Szwarca. Referat dotyczący biografii Waginowa (Личность Константина Вагинова по воспоминаниям его жены) przedstawił Siergiej Kibalczik. Z kolei Maria Inge-Wiecztomowa przypomniała postać Waletina Stienicza, oryginalnego pisarza i wybitnego tłumacza (Валентин Стенич и его окружение (М.В. Больщиниов и Л.Д. Большиниова-Стенич)). Twórczość Jewgienija Szwarca, dramaturga, scenarzysty, ale także felietonisty i redaktora leningradzkiego wydawnictwa dla dzieci przybliżyła w swoim referacie Jelena Woskobojewa (Евгений Швари - редактор).

Jednym z najbardziej znamienitych mieszkańców legendarnego domu nad Mojką był Borys Eichenbaum, wybitny krytyk literacki, jeden z głównych przedstawicieli rosyjskiej szkoły formalnej. Jego działalność literacką przybliżył petersburski badacz Igor Suchich (Б.М. Эйхенбуам: литературовед, писатель, надписатель). Kolejne referaty, akcentujące różny stopień przynależności poetów i pisarzy do petersburskiego i leningradzkiego kanonu, poświęcone były Oldze Forsz i Maksymowi Gorkiemu (Tamara Biełowa, О.Д. Фори в переписке М. Горького кониа 20-x - начала 30-х г2.: вопросы мировоззрения и творчества), twórczości braci Strugackich (Władimir Sobol, Революиия субъекта: два издания одной повести братьев Стругаиких), przekładom poezji Wsiewołoda Rożdiestwienskiego (Swietłana Mieżericka, Milena Rożdiestwienska, O проблемах художественного перевода 
и трудностях переводчика (по материалам эпистолярного наследия Вс. Рождественского)).

Kwestiom zachowania pamięci w przestrzeni miejskiej poświęcił swoje wystąpienie Konstantin Uczitiel (Genius Loci: места памяти и эволюиия культурных институтов), historyk teatru, autor wielu projektów artystycznych, których celem jest przywrócenie pamięci o ważnych miejscach, związanych z życiem kulturalnym Petersburga. Na zakończenie Nina Silinska, kustosz Muzeum Literatury XX wieku, opowiedziała zebranym o jego działalności, nowych książkach i nowych planach.

Konferencja „Literatura jednego domu”, a także inne wydarzenia kulturalne, organizowane przez Muzeum: wystawy, wieczory poezji, spotkania autorskie, akcje performatywne, odbywające się w przestrzeni miejskiej, stały się ważnym elementem życia kulturalnego Petersburga. Wydobywają one z niepamięci i przybliżają życie i twórczość mieszkańców domu nr 9 nad kanałem Gribojedowa, snując nieprzerwaną opowieść o fenomenie literatury rosyjskiej. 